\title{
Community Economic Empowerment through Creative Economic Program in a Business Cooperative in Setu District, Tangerang Selatan
}

\author{
Syahrullah', Muhtadi $^{2}$ \\ ${ }^{1}$ State Islamic University Syarif Hidayatullah Jakarta, Indonesia (kuliahsyahrullah@gmail.com) \\ ${ }^{2}$ State Islamic University Syarif Hidayatullah Jakarta, Indonesia (muhtadi@uinjkt.ac.id)
}

\begin{abstract}
This study aims to determine the process and results of empowering the community's economy through the creative economy program at the Cipta Boga Multipurpose Cooperative. This research was conducted using a qualitative research approach with a descriptive type of research. The data collection techniques used, namely: observation, interviews, and documentation studies. Observations were carried out thematically about the process of community empowerment in the creative economy. Five informants were interviewed, consisting of the management of the cooperative and three program beneficiaries. The selection of informants is based on the fact that they know and are involved in empowerment activities. The documentation study was conducted by collecting data on the process and empowerment program in the creative economy sector at the cooperative. This study indicates that community economic empowerment through a paper bag training program can improve the welfare of the Kranggan village community. The Seba Usaha Cipta Boga Cooperative carries out the stages of community empowerment, starting from planning, implementation, institutionalization, and monitoring evaluation. The influence of the training program results can be seen from the behavior and economic life of the community. People get additional income, increase knowledge in entrepreneurship and get activities for entrepreneurship.
\end{abstract}

Keywords: KUBE, community empowerment, creative economy.

\begin{abstract}
ABSTRAK
Penelitian ini bertujuan untuk mengetahui proses dan hasil yang didapat dalam pemberdayaan ekonomi masyarakat melalui program ekonomi kreatif di Koperasi Serba Usaha Cipta Boga. Penelitian ini dilakukan dengan menggunakan pendekatan penelitian kualitatif dengan jenis penelitian deskriptif. Adapun teknik pengumpulan data yang digunakan, yaitu: observasi, wawancara, dan studi dokumentasi. Observasi dilakukan secara tematik tentang proses pemberdayaan masyarakat di bidang ekonomi kreatif. Informan yang diwawancarai sebanyak lima orang terdiri dari pengurus dan pengelola koperasi, serta tiga penerima
\end{abstract}


manfaat program. Pemilihan informan didasarkan karena mereka mengetahui dan terlibat dalam kegiatan pemberdayaan. Studi dokumentasi dilakukan dengan pengumpulan data mengenai proses dan program pemberdayaan di bidang ekonomi kreatif pada koperasi tersebut. Hasil dari penelitian ini menunjukan bahwa pemberdayaan ekonomi masyarakat melalui program pelatihan paper bag dapat meningkatkan kesejahteraan masyarakat kelurahan Kranggan. Koperasi Seba Usaha Cipta Boga melakukan tahap-tahap pemberdayaan masyarakat mulai dari perencanaan, pelaksanaan, pelembagaan dan evaluasi monitoring. Adapun pengaruh dari hasil program pelatihan tersebut terlihat dari perilaku dan kehidupan ekonomi masyarakat. Masyarakat mendapatkan penghasilan tambahan, menambah pengetahuan dalam berwirausaha dan mendapat kegiatan untuk berwirausaha.

Kata kunci: KUBE, pemberdayaan masyarakat, ekonomi kreatif

\section{INTRODUCTION}

Poverty is one of the social problems that are always relevant to be studied continuously. It is not only because the problem of poverty has existed for a long time and is still present today, but also because now the symptoms are increasing in line with the multidimensional crisis still being faced by people-the Indonesian nation (Suharto 2005: 131). Poverty in Indonesia in March 2017 was published by the Central Statistics Agency (BPS). According to BPS, the number of poor people with monthly per capita expenditure below the poverty line in March 2017 in Indonesia reached 27.77 million people or 10.64 percent of the total population of Indonesia. (Central Bureau of Statistics 2017).

Economic empowerment should be a priority for the government by orienting the poor who desire to be independent by creating their jobs. Especially housewives or women who depend on income and financial input from a working husband. Meanwhile, income and spending are not balanced with the increase in the family's needs per year.

Social welfare development is a planned and institutionalized effort that includes various forms of social intervention and social services to meet human needs (Suharto 2010: 4). The process of social change that is planned and designed to improve the community's standard of living, where the development is carried out, is complementary to economic development. In Indonesia, the word development has been interpreted as advancing the community's and citizens lives (Huraerah 2011: 12). The role of the government in facilitating the development of regional infrastructure is needed to improve services and management of infrastructure in the regions.

Community empowerment is a process of growth and development of community power to be involved in various aspects of development in an area. Empowerment can free people from backwardness and poverty to compete with the outside world (Almasri \& Desmiwar 2014: 42). Research that confirms that community empowerment can solve poverty and improve welfare includes; first, the Weekly Group Credit Program (PKKM) has increased the independence and welfare of the community. Independent in making decisions to carry out activities related to increasing the capacity of the beneficiaries and the income generated from strengthening capital from PT. BPR (Rabbani et al. 2021). Second. Through the concept of community-based tourism, the tourism village program provides positive outcomes, namely the growth and development of an 
economic mindset, the emergence of new livelihoods, increased income and more efficient financial management, and changes in work methods and behavior (Wibhisana 2021). Third, the Zakat Community Development program in the Loa Kumbar area has succeeded in producing around $50 \%$ of the previously unemployed population to have jobs (Lestari and Tikawati 2019). Fourth, the development of tourism objects in Wawoangi Village has increased the pace of the community's economy through handicrafts that have a selling value from the results of their creativity (Lia et al., 2021). Fifth, the success of the Muktiharjo Kidul Village Government in empowering its community through the roles of LPMK, BKM, PKK, and other institutions has been able to create an independent and empowered society (Suharto, 2021).

The creative economy is a concept to realize sustainable economic development based on creativity, such as using renewable and even unlimited resources, namely ideas, and creativity. The economic value of a product or service in the creative era is no longer determined by raw materials or production systems as in the industrial era, but rather the utilization of creativity and the creation of innovation through increasingly advanced technological developments. Industry can no longer compete in the global market by relying solely on price or product quality but must compete based on innovation, creativity, and imagination.

\section{METHOD}

This study aimed to determine the process and results of empowerment carried out by the Cipta Boga Multipurpose Cooperative in the empowerment program for making cardboard bags. The approach used is qualitative research. According to Bogdan and Taylor, quoted by Moleong stating that qualitative research methods are research procedures that produce descriptive data in written or spoken words from people and observed behavior (Soehadha 2018: 175). The type of research is descriptive qualitative. The main characteristics of descriptive research are: a. Focusing on problems that existed when the research was conducted (currently) or actual problems. b. Describing the facts about the problem under investigation as they are, accompanied by a rational interpretation (Nawawi, 1991: 31).

The research location is KSU Cipta Boga, Setu District, South Tangerang City. We were collecting data using in-depth interviews, observation, and documentation. Informants in this study were determined by purposive sampling. The interviewed informants were five people, consisting of 1 founder, 1 Management of KSU Cipta Boga, and three members. The validity of the data is done through the triangulation of sources. Data analysis was carried out in a descriptive (nonstatistical) way.

\section{RESULTS AND DISCUSSION}

\subsection{The Empowerment Process Carried Out by the Cipta Boga Multipurpose Cooperative in the Creative Economy Program}

Creative economy programs at KSU Cipta Boga, Setu District, South Tangerang City, Community economic empowerment empower the creative economy at KSU Cipta Boga provides training to increase income and reduce unemployment in South Tangerang City. Based on the results of interviews from several sources, including the founder of KSU Cipta Boga, cooperative 
management, and cooperative members, the author will describe the results of the field findings through observation and documentation, and field notes.

In this case, community economic empowerment is an effort to provide knowledge, skills and foster self-confidence and a strong will in a person to build a better socio-economic life with their strength. In short, socio-economic empowerment intends to create self-reliant people in socioeconomic activities. In essence, community economic empowerment can be pursued through various activities, including training, mentoring, counseling, education, and organizational involvement to grow and strengthen motivation in life and business and develop knowledge and life skills and work.

The Multipurpose Business Cooperative (KSU) Cipta Boga has carried out empowerment. However, this empowerment is a bit different in general because empowerment is by developing SME business actors who are members of the Cipta Boga Multipurpose Cooperative (KSU) in Kranggan Village, Setu District, South Tangerang City. For smooth empowerment carried out by the Cipta Boga Multipurpose Cooperative (KSU), it is carried out with several stages of empowerment programs carried out within the KSU Cipta Boga cooperative environment:

\section{Planning Stage}

Planning has a significant role in seeing how community participation manages village finances. The level of community participation, in general, can be seen from the participation of the community who consciously and voluntarily participate in various forms ranging from planning to participating in various things in the village. The form of community contribution is in the form of energy and can be the fruit of thoughts. Community involvement is one of the essential keys to builders' success.

\section{a. Process}

In the early stages of the empowerment planning process carried out by the Cipta Boga Multipurpose Cooperative through training in making paper bags, it is the initial stage of the awareness process and the formation of conscious and independent behavior to increase the capacity of members of the Cipta Boga Multipurpose Cooperative. Paper bag training is one of the empowerments carried out by KSU Cipta Boga in collaboration with the government. The selection of paper bag training is based on the needs and potential of the community. Activities carried out by the community are managed by KSU Cipta Boga in collaboration with the government and related institutions. In the planning process, KSU Cipta Boga identified needs by looking at the potential of the community to use paperboard as a raw material for production. Then KSU Cipta Boga invited the public to be aware of the importance of training activity to improve the economy of the members of the Cipta Boga Cooperative.

One of the research findings is about the planning stage in forming cooperatives. The planning stage includes mass identification, introduction, and acceptance of cooperative members. More about the planning stage, Mr. Alwani as the founder of KSU Cipta Boga, revealed the process of introducing the Cipta Boga Multipurpose Cooperative to the public. The following are the results of the interview with by the founder of the Cipta Boga Multipurpose Cooperative, Mr. Alwani, as follows: "In the process of introducing cooperatives, the management and members are gathered back and then socialized about the formation of cooperatives; the method used in the introduction stage is socialization to the community. I invite the community in the hope of participating in the 
formation of cooperatives. I socialized the training that will be held as there was training on making paper bags, which is the lack of community participation. The community initially did not respond to this training, but after some socialization, the community began to arrive." (Interview with Pak Alwani, 2019).

b. Method

In the planning process, the method used is deliberation to inning to be carried out by KSU Cipta Boga. Members of KSU Cipta Boga have mutually agreed upon paper bag training for many reasons and benefits obtained in the implementation of bag training. As stated by the founder of the Cipta Boga Multipurpose Cooperative, Mr. Alwani as follows: "Those involved in the process are the management and members of KSU, who initially moved to form a cooperative until now. The method used is interviews and discussions with the community involved to discover the problems. The results obtained are community input that provides suggestions and what they want to develop further." (Interview with Pak Alwani, 2019).

c. Participants

Participants took part in the planning process by determining the training management. Mr. Lalwani as the chairman of KSU Cipta Boga, determines who will be the administrator in training; the selection is based on looking at the available time in daily activities and the potential of the members participating in the training. It is as expressed by the founder of the Cipta Boga Multipurpose Cooperative, Pak Alwani, as follows: "Those involved in the planning process are the management and members of my KSU, who initially moved to form a cooperative until now." (Interview with Pak Alwani, 2019).

d. Output

The outputs in this planning process are the approval of a paper bag training program, organizers in paper bag training, member acceptance, and the continuation of the training process. As stated by the founder of the Cipta Boga Multipurpose Cooperative, Pak Alwani as follows: "Anyone can join this cooperative and take part in the available training. Because we use the open method, many people participate and thank God there are no obstacles." (Interview with Pak Alwani, 2019).

\section{e. Constraint}

Constraints in the planning process are in the identification of needs. When identifying needs, a deliberation or meeting is held; in this case, many different opinions must be accommodated first. As stated by the founder of the Cipta Boga Multipurpose Cooperative, Pak Alwani as follows: "In the acceptance process, the members involved were, I coordinated with the RT and RW and the Kranggan village. Anyone can join this cooperative and take part in the available training. Because we use the open method, many participate, and thank God, there are no problems. There are obstacles, such as people's perceptions as some people have different opinions with each other so that I will accommodate the community's input first." (Interview with Pak Alwani, 2019).

Thus, the planning stage carried out by KSU Cipta Boga aims to invite the public to participate in the program held by KSU Cipta Boga. The process uses an open method through interviews and joint discussions to get input from the community regarding the training that will be held in the paper bag-making training program. It was also expressed by members of the Bulia cooperative, as follows: "Housewives hehe, so what are we doing because we used to sell chips often, we were in 
the business of chips, cassava chips, bananas, before that we were doing business? There is training; it is not biased, there is also a mentor who teaches it from Bandung, his name is Pak Syaifudin, he is the one who teaches us so we can do it, later when we are biased, we give activities to women in Kranggan." (Interview with Mrs. Lia, 2019).

As the result of the interview above, it was stated that before joining KSU Cipta Boga, the community had never attended any training. However, some people already opened their businesses. This training can increase the income of the people who attend KSU Cipta Boga, reduce the unemployment rate, and increase members' knowledge.

\section{Program Implementation Phase}

At this stage, it becomes a crucial stage because it is part of the implementation of various formulations and plans that have been made previously. This stage is carried out starting from socialization, discussion, and training activities in which theoretical and practical training materials are given. Of course, after carrying out the planning stage of the training program, then through the program implementation stage. In the implementation phase of this program, there are several steps in implementation, namely process, method, participants, output, and constraints.

a. Process

In the process carried out at the program implementation stage, the activities carried out are interactive educational activities. Educational interaction activities are a reciprocal relationship between one individual and another that occurs in the community or other than the community. Thus, in the community's educational interactions, the community participates in training activities carried out by KSU Cipta Boga. As stated by the founder of the Cipta Boga Multipurpose Cooperative, Pak Alwani as follows: "The community is gathered to be informed about the introduction of the cooperative and the training held. The community is enthusiastic about participating in the activities in the cooperative, and the constraints are time and place." (Interview with Pak Alwani, 2019).

More deeply about the paper bag training process involved, namely members of the cooperative, the community gets knowledge about making paper bags. The problem is that there has been no follow-up on cooperation with other entrepreneurs. Furthermore, in the implementation process, the Bulia cooperative members stated further, as follows: "There is training. Can't we do it? There is also a supervisor who teaches it from Bandung; his name is Pak Syaifudin, he is the one who teaches us so we can do it, later when we can release activities for mothers in Kranggan." (Interview with Mrs. Lia, 2019).

b. Method

In this case, the selection of training methods must be appropriate to facilitate the delivery of training materials. Also, the training methods applied must be following the type of training material and the abilities of the trainees. In paper bag training, the method used is face-to-face training. As stated by the founder of the Cipta Boga Multipurpose Cooperative, Pak Alwani as follows: "Indirect face-to-face and previously the community was gathered to be informed about the introduction of the cooperative and the training held, the community was enthusiastic about participating in the activities in the cooperative, and the constraints were time and place" (Interview with Pak Alwani, 2019). 
Inviting the community to come directly to the training site and participate in the training can make it easier for the community to participate in the training. The same thing was expressed by a member of the Bulia cooperative, as follows: "Mr. Alwani gave the training, didn't Mr. Alwani initially give us a letter, and then we were told the group to join the training. There are ladies and gentlemen too; the gentlemen also join the cooperative, it's like all kinds of business in the business field, like selling anything, for example, sangria peanut chips, like that, that's all. I just joined the training and her name was also a housewife insight" (Interview with Bu lis, 2019)

c. Participants

Some of them who directly involved in the implementation phase were members, the community, and support from the surrounding RT RW. As stated by the founder of the Cipta Boga Multipurpose Cooperative, Pak Alwani as follows: "Those involved are members and the community, I invite the surrounding community including RT and RW." (Interview with Pak Alwani, 2019).

In this case, the community actively participates in the paper bag training with their own will, without force, as participation is voluntary. The community began to be interested in participating in the training and became aware of the benefits obtained after. As expressed by a member of the Bulia cooperative, as follows: "Yeah, I'm going, I'm participating in the paper bag training that the Bandung people trained. Thank God I can now make my paper bags."(Interview with Mrs. Lia, 2019). The cooperative members Mrs. Ipah and Mrs. Oca, expressed the same thing, as follows: "Yes, if I have no other schedule, or family matters, I will join." "Yes, join the training." (Interview with Mrs. Oca, 2019).

d. Output

In this case, people who have experienced the learning process in paper bag training affect the benefits received by training members. Includes improving living standards, getting learning activities or knowledge, and increasing abilities. It was expressed by a member of the Bulia cooperative, as follows: "Yeah, I'm going, I'm taking part in the paper bag training with people from Bandung, thank God now I can make my paper bag." (Interview with Mrs. Lia, 2019). The same thing was expressed by a member of cooperative, Bu Ipoh, as follows: "Alhamdulillah, the children have extra snacks. While waiting for the children to come home from school and when the family matters are finished, I look for activities that are productive with flexible time." (Interview with Mrs. Ipah, 2019).

The same thing was expressed by another member of the cooperative, Bu Oca, as follows: "Yes, it is quite helpful, as well as lightening the burden on my husband. I just want to come along and increase the family's income. Yes, save, right in a cooperative, there is a mandatory deposit that is deducted from income." (Interview with Mrs. Oca, 2019).

Pak Idang cooperative member expressed the same thing, as follows: "Alhamdulillah, it was helped to increase the school fees for children, so I do not worry too much about school fees." (interview with Pak Idang, 2021).

\section{e. Constraint}

In this case, the problem with paper bag training is making paper bags. As for the people who have just joined the training, of course, they are still stiff in carrying out training activities and find it difficult. Some people have difficulties with the cardboard material shaped into paper bags due to 
the different levels of thickness in each carton provided. As expressed by cooperative member Bu Oca, as follows: "What, the folding part is quite difficult" (Interview with Mrs. Oca, 2019). The same thing was expressed by a member of the bu lis cooperative, as follows: "The raw materials are easy when they are made, when the ingredients are too hard, so their hands hurt. Use a comb for it, use the edge of a comb" (Interview with Bu lis, 2019).

This was also expressed by members of the cooperative, Mrs. Lia and Mrs. Ipah, as follows: "What is it? If the material is thin, it is easy. If the material is thick, it is not easy. The raw material is easy when making it, when the material is too hard, so your hands hurt. Use a comb for it, use the edge of the comb" (Interview with Mrs. Lia, 2019). "The problem is that at the time, when it was still good to make cardboard bags, the family had already called. But it is already an obligation." (Interview with Mrs. Ipah, 2019).

\section{Institutionalization Stage}

This institutionalization stage is a unique stage carried out to build aspects of independence or sustainability. Several organizers often neglect this stage in community empowerment programs to run sustainably and provide long-term benefits to the community and ensure that the program remains productive even though the assistance/assistance from the program implementing agency has been completed.

The stages of community empowerment that ignore the sustainability aspect (institutionalization) do not contribute to the development of a more sustainable program. Mentoring is a process to achieve independence. Mentoring in economic empowerment here, $\mathrm{Mr}$. Alwani becomes a mentor by controlling and asking entrepreneurs about everything related to cardboard production.

a. Process and Method

With the Cipta Boga Multipurpose Cooperative, which Mr. Alwani founded, then in the cooperative, a training program was initiated for the surrounding community as members of the Cipta Boga KSU. As stated by the founder of the Cipta Boga Multipurpose Cooperative, Pak Alwani as follows: "I do coaching with the hope that this cooperative can develop and also the management and members can increase their knowledge in the business field. As for the management, I directly develop, such as involving the management in the training and education in the Kranggan village so that they can provide their knowledge again to the community or members." (Interview with Pak Alwani, 2019). Coaching is an effort in empowerment that needs to be carried out continuously and progressively in order to achieve the expected results. The coaching carried out by KSU Cipta Boga teaches how to choose the training program to be implemented, money management, and marketing. The training method used is coaching through training. It makes it easier for the KSU Cipta Boga management to master the knowledge and abilities to guide community members in paper bag training.

b. Participants

In this case, those directly involved in the institutionalization stage are Mr. Alwani as the chairman of the Cipta Boga Multipurpose Cooperative and the management of the Cipta Boga Multipurpose Business Cooperative.

c. Output 
Increased knowledge and skills can improve the quality of the Cipta Boga Multipurpose Cooperative management. So that it has a positive impact on the training carried out by the Cipta Boga Multipurpose Cooperative. As stated by the founder of the Cipta Boga Multipurpose Cooperative, Pak Alwani as follows: "The knowledge gained by the management of the Cipta Boga Multipurpose Cooperative during training and education training, and improving the quality of the cooperative." (Interview with Mr. Alwani, 2019).

\section{d. Constraint}

In the institutionalization stage, the obstacles exist and certainly affect the process of the institutionalization stage. Managers in training have different or heterogeneous backgrounds, such as education, work experience, and age. It results in difficulties and hindering the smooth implementation of the training program. It results in low community participation in the training program management at KSU Cipta Boga. As stated by the founder of the Cipta Boga Multipurpose Cooperative, Pak Alwani as follows: "Low member participation in cadre management." (Interview with Mr. Alwani, 2019).

\section{Monitoring and evaluation stage}

Monitoring is an evaluation activity carried out in ongoing program implementation activities. Therefore, in monitoring activities, more data is needed. The data should be in the form of reports from the implementation of activities or the results of direct observations of the activities carried out and the results of activities that have been achieved.

\section{a. Process and Constraints}

In the program evaluation stage, the analysis returns to the beginning of the planning process to determine whether the stated objectives can be achieved. Evaluation makes planning a continuous process. Evaluation can only be carried out if the plan has been implemented. As stated by the founder of the Cipta Boga Multipurpose Cooperative, Pak Alwani as follows: "In the evaluation process, the cooperative includes the management and members of the cooperative, through a meeting of the management and members. From the meeting, the results of the evaluation can be seen regarding increasing knowledge, quality, and income. However, the obstacle is the lack of community participation." (Interview with Pak Alwani, 2019).

At the evaluation stage, the process went well by involving the management and cooperative members in every meeting. Thus, the needs of the members will be immediately conveyed during the meeting, although problems cannot be avoided. The obstacle that occurs is the low level of community participation. Not all members attended the meeting due to people with heterogeneous backgrounds having different work status and age. These obstacles certainly impact the implementation of the training, although not significantly.

b. Method and Output

The Cipta Boga Multipurpose Cooperative has a training program that aims to increase the knowledge and income of the surrounding community as members of the cooperative. Furthermore, in the evaluation and monitoring stage, an analysis of the training program's success is carried out by holding meetings or deliberation related to training. The participants who took part in the evaluation and monitoring were the Chairperson of the Cipta Boga KSU, the management of the Cipta Boga KSU, and also the members of the Cipta Boga KSU. With community members in the 
evaluation and monitoring stage, it is hoped that they can experience firsthand the progress of the program that has been held. The evaluation is held after the members complete the training program.

Several members also revealed things about the evaluation stage. It was revealed by members of KSU Cipta Boga, Mrs. Ipah, and Mrs. Oca: "Science, knowledge, and socialization continue to be here; the togetherness is perfect. It is like after training you like to be asked about difficulties in training and what is needed in training." "There is a lot, the experience and knowledge of the training is also good. We give directions for our respective efforts, yes, it is rich with motivation." (Interview with Mrs. Oca).

In this case, members who have completed a training program at KSU Cipta Boga are included in the evaluation meeting. Increase in income. As expressed by the founder of the Cipta Boga Multipurpose Cooperative, Mr. Alwani as follows: "The results of the evaluation meeting, so we can know about the increase in members' knowledge, the quality of the training we carry out and the income they get." (Interview with Pak Alwani 2019).

\subsection{Results of Community Economic Empowerment}

The results obtained by community members after joining the Multipurpose Cooperative Cipta Boga are an increase in economic terms (income) and independence in entrepreneurship. If we relate this to the theory put forward by Almasri and Devi Deswimar (2014: 42), community empowerment is an effort to increase power or strength in the community by providing encouragement, opportunities, opportunities, and protection by not regulating and controlling community activities that empowered to develop their potential so that the community can improve their abilities and actualize themselves or participate through various activities. Community Empowerment is a process of growth and development of community power to be involved in various aspects of development in an area. Empowerment can assist people to gain freedom and avoid poverty to compete with the outside world.

The idea of the training program carried out by the Cipta Boga Multipurpose Cooperative explores the community's potential. It encourages the community's growth to gain better social and economic conditions. It will also help KSU Cipta Bogor to place itself as an organization improving the creative economy.

In this case, the creative economy is a concept to realize sustainable economic development based on creativity. The utilization of renewable but not even limited resources is ideas, talents or talents, and creativity. The economic value of a product or service in the creative era is no longer determined by raw materials or production systems as in the industrial era, but rather the utilization of creativity and the creation of innovation through increasingly advanced technological developments. Industries can no longer compete in the global market by relying solely on price or product quality but must compete based on innovation, creativity, and imagination.

The rules that exist in society to meet their living needs are fundamental in addition to being a means of satisfying their needs and carrying out their daily lives. The method referred to here relates to the activities of people and society related to the production, distribution, exchange, and consumption of services and rare items (Ismet dan Asep Usman, 2008:221). KSU Cipta Boga's effort has helped in reeducing poverty levels around KSU Cipta Boga, which is located in the Kranggan 
Village, South Tangerang. One of the methods used to reduce poverty in developing the community's potential and motivating empowerment targets.

Based on the data found in the field, the training carried out at KSU Cipta Boga for members can be the initial capital owned by each member of the cooperative. The capital mentioned is that every member who wants to join in the cardboard bag craft at KSU Cipta Boga needs to make cardboard bags. With the training in this cooperative, the abilities obtained can be the basis or capital owned by each member. To open a cooperative, each member must have the ability and experience in the field.

From an economic perspective, the empowerment process carried out at KSU Cipta Boga has an impact or result that can increase economic empowerment for cooperative members. From some field findings, the author will analyze the process and results in empowering the community's economy through the creative economy program carried out by the Cipta Boga Multipurpose Cooperative. Analysis of the paper bag or cardboard bag training program conducted by KSU Cipta Boga in empowering the Kranggan village community. In this case, the author will describe the discussion using further descriptive analysis regarding descriptive analysis, namely a narrative discussion. After going through field observations, it can be seen that the majority of the people of the Kranggan village have their own business so that the business does not develop. Based on some of the author's information in the field, people often find it difficult to market their products and feel their lack knowledge in other fields of work. It creates a new problem which is unemployment in the Kranggan village.

With these problems, the Cipta Boga Multipurpose Cooperative was established, founded by Mr. Alwani. Establishing the Cipta Boga Multipurpose Cooperative is expected to solve these problems. In addition, the Cipta Boga Multipurpose Cooperative makes training programs for the community to increase knowledge and skills in the business field. The problem of community empowerment is one of the essential activities that need to be carried out to empower, especially for groups considered weak and vulnerable to poverty. Thus, they have the ability and strength and can free themselves from various adversity, backwardness, and backwardness. In addition, they desire to become an advanced, independent group and have all its needs met (Haris 2014: 51). In other words, the training program carried out by the Cipta Boga Multipurpose Cooperative is able to give strength to the community to rise and develop towards a more advanced business.

\subsection{Creative Economy Program at the Catering Multipurpose Cooperative}

The Cipta Boga Multipurpose Cooperative has helped the surrounding community reduce the unemployment problem. The method used to reduce the unemployment rate is by developing community potential, providing knowledge related to their potential, and motivating empowerment targets or the surrounding community. According to Kieffer (1981), it is under the theory that empowerment includes three dimensions: people's competence, sociopolitical ability, and participatory competence. The theory also proposes three dimensions of empowerment which refer to: (1) The development process begins with individual growth, which develops into a more significant social change. (2) A psychological state is characterized by self-confidence, usefulness, and control over oneself and others. (3) Liberation resulting from a social movement begins with 
the education and politicization of the weak. It then involves the collective efforts of these weak people to gain power and change the structures that are still oppressive.

Quoting from the Creative Economy Blueprint 2025, 3 main things are the basis of the creative economy, including creativity, innovation, and invention. (1) Creativity. Based on the results of observations made by KSU Cipta Boga, creativity is a breakthrough in the cooperative because KSU Cipta Boga makes paper bags that can replace plastic bags as a place for shopping to reduce waste. (2) Innovation. The Cipta Boga Multipurpose Cooperative created a paper bag training program. It then innovated it with direct marketing to sales stores to generate money to increase income and be more useful in their future businesses. Based on the results of the observation of innovations made by KSU Cipta Boga in making paper bags, namely utilizing used paper which is made into paper pulp, then used and processed to produce paper bags. (3) Invention. In this case, the creative economy program initiated by the Cipta Boga Multipurpose Cooperative can help the community become more empowered. A creative economy is essentially an economic activity that prioritizes creative thinking. The Cipta Boga Multipurpose Cooperative emphasizes creative thinking as in the paper bag training program, in that the training is not only given knowledge about the manufacture and process. However, the training continues until the marketing stage so that the community can improve their economy.

\section{CONCLUSION}

Empowerment was carried out by the Cipta Boga Multipurpose Cooperative (KSU). Program cooperative members have been assisted from the planning, implementation, institutionalization, and monitoring and evaluation stages with various methods, processes, and problems. The results of Community Economic Empowerment show that cooperative members have creativity and innovation in making paper bags. Another exciting thing is that community empowerment for cooperative members is facilitation for promotion for the paper bag. Cooperative members can increase their income and savings.

\section{REFERENCES}

Almasri, and Devi Desmiwar. (2014). "Peran Program Pemberdayaan Masyarakat Desa dalam Pembangunan Pedesaan." Jurnal Fakultas Ekonomi dan IImu Sosial Universitas Islam Negeri Sultan Syarif Kasim Riau.

Berita Resmi Badan Pusat Statistik. (2017). "Profil Kemiskinan di Indonesia. No. 66/07/Th. XX, 17 Juli 2017." Badan Pusat Statistik. Retrieved December 2, 2017 (http://www.bps.go.id).

Haris, Andi. (2014). "Memahami Pendekatan Pemberdayaan Masyarakat melalui Pemanfaatan Media." JUPITER XIII(2).

Huraerah, Abu. (2011). Pengorganisasian dan Pengembangan Masyarakat. Bandung: Humaniora. Ismet Firdaus, Asep Usman Ismail. (2008). Economic empowerment of poor people in Bojong Indah Village according to Islam; collection of articles. Dakwah Press, Universitas Syarief Hidayatullah Jakarta.

Kieffer, C. H. (1981). The emergence of empowerment: The development of participatory competence among individuals in citizen organizations: I \& II. Dissertation Abstracts International, 42(6-B), 2566. 
Lestari, Eka Dwi, and Tikawati Tikawati. (2019). "Analisis Peran Program Zakat Community Development BAZNAS Kota Samarinda Dalam Mengurangi Kemiskinan Di Samarinda." Al-Tijary 5(1):59-73.

Lia, Hanifa, Azaluddin, Arjuwita, Karlina Ayu Rezky, and Riskawat. (2021). "Pemberdayaan Masyarakat Melalui Pendekatan Modal Sosial Dalam Pengembangan Obyek Wisata Di Desa Wawoangi." COMMUNITY EMPOWERMENT 6(6):1029-36.

Nawawi, Hadari. (1991). Metode Penelitian Bidang Sosial. Yogyakarta: Gadjah Mada University.

Rabbani, Gian, Faisal Muzzammil, Umi Rojiati, and Agus Kurniawan. (2021). "Pemberdayaan Ekonomi Melalui Program Kelompok Mingguan (PKKM) Dalam Meningkatkan Kesejahteraan Masyarakat." Al-Mu'awanah: Jurnal Pengabdian Kepada Masyarakat 2(1):30-42.

Soehadha, Moh. (2018). Metode Penelitian Sosial Kualitatif Untuk Studi Agama. Yogyakarta: Suka Press UIN Sunan Kalijaga.

Suharto, Edi. (2005). Membangun Masyarakat, Memberdayakan Masyarakat. Bandung: PT Refika Aditama.

Suharto, Edi. (2010). Membangun Masyarakat, Memberdayakan Masyarakat. Bandung: PT Refika Aditama.

Suharto, Suharto. (2021). "Keberhasilan Pemerintahan Kelurahan Dalam Pemberdayaan Masyarakat Kelurahan Di Kota Semarang." QISTIE 14(1):41-63.

Wibhisana, Yohanes Putut. (2021). "Pemberdayaan Masyarakat Dan Komunitas Dalam Program Desa Wisata Jogoboyo Purworejo." Aspirasi: Jurnal Masalah-Masalah Sosial 12(1):31-45. 